ACTA UNIVERSITATIS LODZIENSIS

FOLIA LITTERARIA POLONICA 5(43) 2017

http://dx.doi.org/10.18778/1505-9057.43.09

Grażyna Habrajska*

\title{
Interpretation of a verbal-visual communication
}

In contemporary internet-dominated everyday life, ever more often one faces communications which utilise both verbal (words) and iconic (images) codes. Such communications within the public space have long functioned in such periodicals as Szpilki (1935-1994), which gathered top Polish visual artists, some of whom, like Henryk Sawka or Andrzej Mleczko, continue to release political commentaries, though today their medium of choice is the internet. That type of communication, in a more pungent form has been maintained in memes. It is often the case that article titles included as captions under photographs possess a similar structure. Another large group of verbal-visual communications consists of static advertisements. Each of those two groups, though similar in terms of the form of communication, requires different interpretations. There are many studies devoted to both advertising communications and memes. One of the most recent publications on advertising is "Manual - reklama. Podręcznik z zakresu projektowania komunikacji" edited by Mariusz Wszołek, where one will find various methods of analysing advertisements ${ }^{1}$. I shall indicate one possible mode of interpretation which supplements Piotr Lewiński's proposal. The analysis and interpretation of memes is considerably more complicated because apart from their persuasive function they also fulfil an ironic or mocking function. Both advertising content and memes belong to opinion discourse ${ }^{2}$, yet memes also refer to comical discourse.

Any communication in order to be understood, requires the focussing of the attention of the receiver. The focus is mainly influenced by the mode of presentation

\footnotetext{
* Prof., e-mail: grazyna.h@hotmail.com; Chair of Communication Theory and Practice, Department of Journalism and Social Communication, University of Lodz.

1 "Manual - reklama. Podręcznik z zakresu projektowania komunikacji”, M. Wszołek (ed.), Wydawnictwo Libron, Wroclaw 2017. Particularly interesting are texts: by Piotr Lewiński "Retoryka jako narzędzie opisu komunikatów reklamowych"; A. Siemes "Badanie reklamy - przegląd perspektyw badawczych w kontekście komunikacji i kultury”, and M. Wszołek "Dyferencje rynkowe w reklamie".

2 The topic of discourse variants and their markers are discussed in more detail by Aleksy Awdiejew in a study "Style argumentacji" (accepted for printing - Cracow 2016), and before that: A. Awdiejew, G. Habrajska, "Wprowadzenie do gramatyki komunikacyjnej", Vol. 2, Oficyna Wydawnicza Leksem, Łask 2006.
} 
of the content. The mode of presentation of the content in an advertisement depends on three main factors: identifiability by receivers, organisation of their attention, and maintaining their engagement ${ }^{3}$. The most difficult part of the entire advertising message is to maintain the engagement of receivers, i.e. the ability to offer them an experience of a product. Therefore, its creators utilise various verbal and visual devices, which include metonymy and metaphor, which stimulate the receivers' imaginations enabling them to participate in the creation of the advertising message. Once stimulated, the imagination triggers a visualisation of a consumption situation and evokes emotions. In line with François Paul-Cavallier's position, it is assumed that a visualisation "is a process of activating sensory (perception-based) and emotional experiences in order to utilise psychological resources for future plans and their execution"4. Future actions resulting from visualisations in the case of advertising should translate into a desire for the product being advertised, and, as a result, striving to purchase it, while in the case of memes, a visualisation should influence a change in the receiver's attitude, mainly through evoking the fear of a threat.

As I have already mentioned, the act of evoking the experience of envisioning a product may be a result of applying metonymy and metaphor. Metonymy is based on a single predicative pattern. It indicates the quantitative scope of information "when its fragment substitutes the whole or [...] the holistic general name is used instead of a more specialised name"s. Metaphors trigger a dual visualisation as they refer to two standard vision layers ( $\mathrm{X}$ is $\mathrm{Y}$ ) shifting the qualities of an object from one layer to an object from the other layer. Instead of acquiring a single reference to an idea-based vision of a specific fragment of reality, the receiver acquires two independent idea-based visions, one of which is associated with that fragment directly, while the other is not ontologically associated with it and remains within the realm of visions. If the receiver notices such a message, she/ he faces the need to solve a type of riddle, which helps seize her/his attention. For example in a statement:

\section{(1) He pounced like a lion on the discounted goods}

one can notice the presence of an updated standard ${ }^{6}$ :

\footnotetext{
${ }^{3}$ A. Awdiejew, "Podstawowe komponenty przekazu reklamowego", in: "Styl - dyskurs - media”, B. Bogołębska, M. Worsowicz (eds.), Wydawnictwo Uniwersytetu Łódzkiego, Lodz 2010.

${ }^{4}$ F.J. Paul-Cavallier, "Wizualizacja. Od obrazu do działania”, transl. by A. Suchańska, Dom Wydawniczy Rebis, Poznan 1994, p. 62.

${ }^{5}$ A. Awdiejew, "Tryby komunikacyjne", in: "W zwierciadle języka i kultury", J. Adamowski, S. Niebrzegowska (eds.), Wydawnictwo Uniwersytetu Marii Curie-Skłodowskiej, Lublin 1999, p. 246.

${ }^{6}$ We record standards which are the equivalents of typical idea-based (vision-based) images in the form of predicative-argumentative arrangements (a1, a2, etc.), where the predicate (P) is the name of the activity, event, state, etc., and arguments (a1, a2) are the names of objects, items, etc. necessary
} 


\section{(2) P: POUNCE [a1: SOMEONE, a2: ON SOMETHING]}

directly associated with the presented situation, a drive towards acquiring a desired product. The metaphorical effect results in a dual substitution ${ }^{7}$ of the first argument in that predicative-argumentative arrangement.

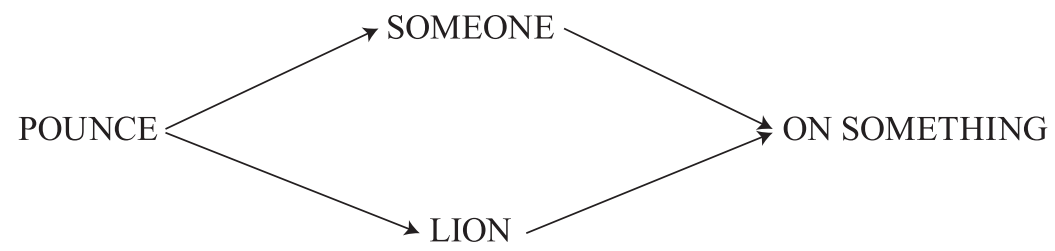

The first argument is the actual originator of the event: someone and his imaginary equivalent: lion, evoking the related set of stereotypes evaluating the entire event, thus assigning the attributes typical for the behaviour of a lion (aggression, strength, predatoriness, speed, etc.) That is possible as a result of the overlapping (blending) of the idea-based image which indicates reality and the imaginary vision which has no direct relationship with reality, yet functionally it is related to the first image through the affinity of grammatical patterns:

(3) P1: POUNCE [a1: SOMEONE, a2: ON SOMETHING]: Someone pounced on something (where the something are the discounted products)

(4) P2: POUNCE [a1: LION, a2: ON SOMETHING]: A lion pounced on something (where the something are other animals which are the lion's food)

Therefore, the metaphor is a dual vision of reality through its direct description (Someone pounced on something) and a reference to imagined visions which are functionally associated with that description (A lion pounced on something). To ensure a clarity of reference, as the isomorphic structure ${ }^{8}$ of a metaphor we consider the formal comparison, which defines the relationships resulting from the blends of standard predicative patterns between those patterns introduced, e.g. by operators: like, as, similarly to, as if, etc.

(5) BE [SOMETHING1 LIKE SOMETHING2]

for understanding. We discussed those issues more closely in: A. Awdiejew, G. Habrajska, "Wprowadzenie do gramatyki komunikacyjnej”, Vol. 1, Oficyna Wydawnicza Leksem, Łask 2004.

${ }^{7}$ In the communication grammar approach, a substitution is a possible exchange of arguments within a single predicative arrangement [Habrajska - in press].

${ }^{8}$ An isomorphic structure is understood as a structure where the form corresponds to the content being communicated. 
Even non-isomorphic relationships of metaphors do not change their internal communication structure, cf.:

(6) wilczy apetyt [wolf's appetite] (epithet) $\rightarrow$ eat greedily like a wolf hunt for someone (metaphorical expression) $\rightarrow$ treat someone like prey (e.g. Janek hunts the directors)

sadness of the skies (metaphor proper) $\rightarrow$ the sky is sad like a human being, etc.

A metaphorical reference to two imagination-based layers in advertising may be included in just the slogan, in the slogan and the image, or potentially in just the image. I discuss all those types of metaphor usage in advertising in the article entitled Metafora $w$ reklamie, which in in press. Here, I shall discuss the mechanism for analysing and interpreting a selected advertisement for SONY cameras. Its metaphor is clear only as a result of the parallel reception of the slogan and the image. Without the image the slogan would be unintelligible. The advertisement's structure is complex; one must undertake a considerable mental effort to understand and interpret it.

Figure 1. Advertisement of SONY cameras

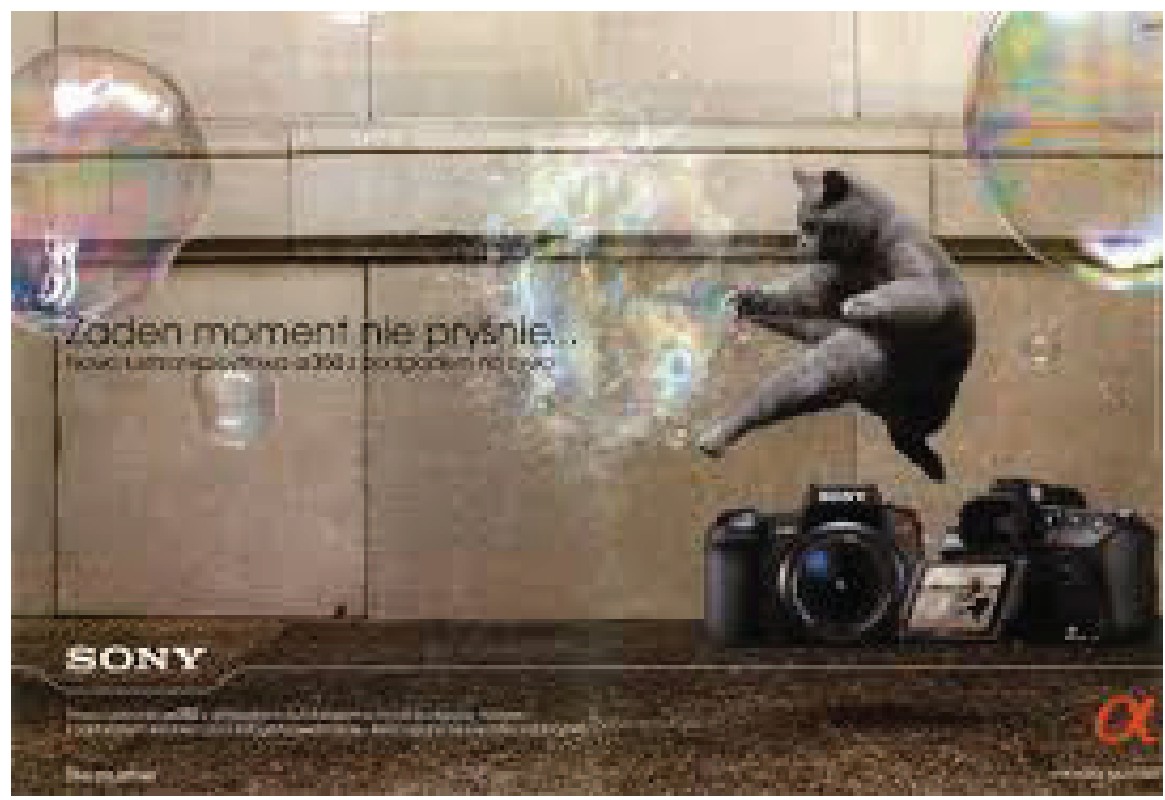

Source: https://www.google.pl/search?q=SONY+reklama\&hl=pl\&tbm=isch\&tbo=u\& source $=$ univ\&sa $=$ X\&ved $=0$ ahUKEwj7pOio3PbQAhVCWSwKHV-7AUwQsAQIJg\&bi $\mathrm{w}=1188 \& \mathrm{bih}=559$ [accessed on: 05.07.2016]. 
The advertisement's slogan: ŻADEN MOMENT NIE PRYŚNIE (no moment will vanish) refers to the common and already metaphorical (in relation to the standard: PRYSNĄĆ (vanish, burst) [SOMETHING: WATER, SOAP BUBBLE, SHARDS, etc.]) meaning of the predicate of PRYSNĄĆ: PRYSNĄĆ [SOMEONE/ SOMETHING], which constitutes an equivalent of the general: WITHDRAW QUICKLY / RUN AWAY [SOMEONE/SOMETHING]. That predicate constitutes the first layer of reference:

(7) (image 1): PRYSNĄĆ [SOMETHING] = RUN AWAY [SOMETHING]

the second layer constitutes a reference to passing time, every life moment of life:

(8) (image 2): QUICKLY > PASS [SOMETHING: MOMENT OF LIFE] = RUN AWAY [SOMETHING: MOMENT OF LIFE]

Through the overlaying of both images, a metaphor is formed:

(9) (metaphor): PRYSNĄĆ (vanish) [SOMETHING: MOMENT OF LIFE], which constitutes a reification of a moment of life - it transfers the qualities of bursting water onto a rapidly passing moment. That metaphor is amplified by the image of soap bubbles and a cat that jumps and bursts them, thus also using the standard meaning of the term PRYSNĄĆ:

(10) PRYSNĄĆ (burst) [SOMETHING: SOAP BUBBLE].

The resulting metaphor constitutes another image:

(11) (image 3): QUICKLY > PRYSNĄĆ (burst) [SOMETHING: MOMENT OF LIFE like a SOAP BUBBLE],

co-forming the slogan with the fourth image:

(12) (image 4): RETAIN [SOMETHING1, SOMETHING2]: RETAIN [SOMETHING1: PHOTOGRAPH, SOMETHING2: EVERY > MOMENT OF LIFE]

The fourth image is supplemented with an indication of the manner of retaining a moment, recording it in a photograph - the fifth image, using the equipment specified in the advertisement (SONY cameras):

(13) (image 5): TAKE PHOTOGRAPHS [SOMEONE, SOMETHING2, USING SOMETHING3]: TAKE PHOTOGRAPHS [SOMEONE, SOMETHING2: ANYONE > MOMENT OF LIFE, USING SOMETHING3: SONY DSLR]. 
That leads to the proper reading of the cause and effect plan, which constitutes the message of the advertisement: if you wish to capture each moment in life, you need to take photographs using a SONY DLSR. The cameras located in the bottom right-hand corner enable one to understand the slogan. However, the inclusion of a cat popping a soap bubble poorly correlates to the message as it only illustrates the fleeting nature of the moment and draws the receiver's attention.

As I have mentioned before, the analysis and interpretation of memes is much more complex. Memes, similarly to static advertisements, constitute dualcode communications, and, just like advertisements, require one to notice and identify an image and text. In their case, it is also necessary to possess discursive knowledge (not expressed either in a verbal or visual communication), based on which the receiver can recreate the situational background of a communication and the particular situation'.

Memes are located within opinion/propaganda discourse, the situational background of which forms the information space, without the knowledge of which one cannot understand the meaning of a communication and its communicational aim. The situational background constitutes an arrangement of problems, tensions and ideological contrasts, which have formed in the political sphere. Within the process of identifying the background, the processes of reduction and contrasting occur. A reduction consists of selecting the most relevant components of the situational background, while contrasting entails increasing the axiological distance between various attitudes ${ }^{10}$. For example, the fact of identifying one person as a leftist (lewak) and another as a true Pole (prawdziwy Polak) is exactly the result of reduction and contrasting. Even the act of coming into contact with a quality results in self-determination. If a person supports a leftist, she/ he is suspected of leftist views, etc. Thus the situational background is not an independent information bank, rather a defined construct within the consciousness of discourse participants who, depending on their political affiliation, choose from it information necessary for fulfilling the intended propaganda goals.

A communication is always evoked by a defined situation (a particular event in the political sphere), which fits a specific situational background, thus defining it further. That situation may refer to the entire background or only fragments of it which are necessary for the interpretation.

${ }^{9}$ A detailed description of the analysis of propaganda texts is included in: A. Awdiejew, G. Habrajska, "Strategie propagandowe i agitacyjne", in: "Rozmowy o komunikacji 3: Problemy komunikacji społecznej”, G. Habrajska (ed.), Oficyna Wydawnicza Leksem, Łask 2009.

${ }^{10}$ The specific attitude expresses a speaker's attitude towards actual objects of reality which exist in the political sphere, and it constitutes a qualifying judgement in an axiological argumentation. Cf. A. Awdiejew, "Argumentacja aksjologiczna", in: "Rozmowy o komunikacji 2: Motywacja psychologiczna i kulturowa w komunikacji”, G. Habrajska (ed.), Oficyna Wydawnicza Leksem, Łask 2008, pp. 129-139. 
The main persuasive goal in propaganda discourse is not to change a receiver's ideological bank, but to accept or reject qualifying judgements regarding actual objects of the political sphere in a specific situation. Memes share that goal. They usually differ from other propaganda texts through their lack of a clearly defined receiver, which is why receivers focus solely on the aim of the message.

Memes are founded not only in propaganda discourse, but also in comical discourse, which mainly utilises irony, mockery and parody, considerably complicating their analysis, interpretation and understanding, as it requires one to possess the ability to identify the communicational goal not only of propaganda but also of comical discourse, which often outranks the former. In other words, it is easier to identify the intention to mock someone or something than to identify the persuasive goal of influencing people to change their attitude towards the person being mocked, her/his behaviour or official decisions. Let us begin with an analysis of a meme by one of the masters: Andrzej Mleczko:

Meme 1.

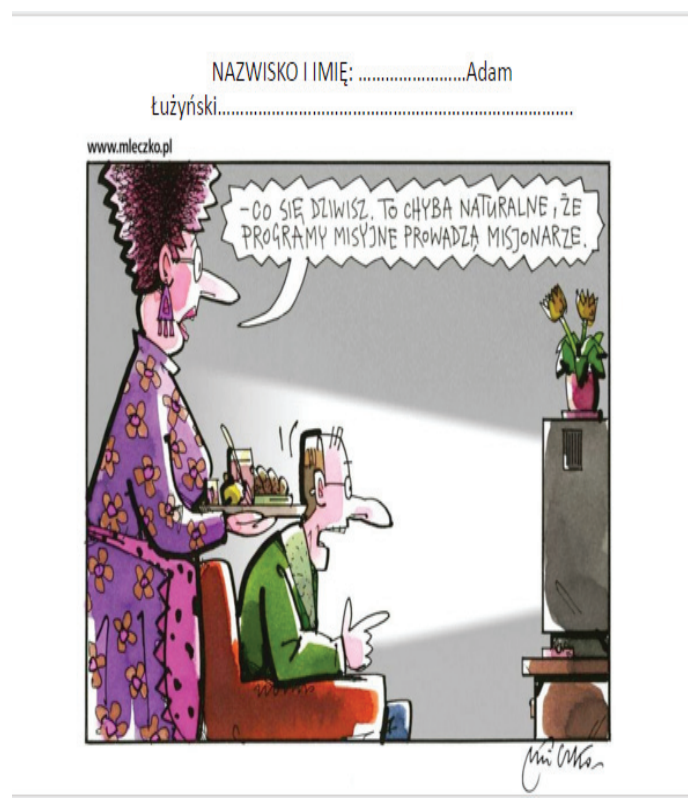

Source: http://mleczko.pl/rysunki-kolorowe [accessed on: 12.12.2015].

The general situational background for that meme was part of the discourse within which the role of the media in community life is discussed. The dispute has always surfaced upon the replacement of one ruling party with another. In it, the views of the representatives of contrasting options clash: some (the opposition) want full freedom of speech, while others want the media to conform to the ruling 
party, regardless of which party has won. The urge to subdue the media has been masked differently by different ruling groups. It is often done under the banner of the mission of the media, i.e. propagating the "only just" views, of course meaning those which are shared by those currently at the helm.

The situation which caused the creation of the meme was the introduction by the Sejm, dominated by PiS (Law and Justice Party) deputies, a new media act, which subdued the so-called public media to the will of the ruling party.

Having specified the general background and the specific situation, we may recreate the argument included in the communication. Upon standardising axiological arguments, we may assume that the first premise is the general judgement / rule, which is known by all those who participate in a given culture or specific ideological group and/or with which they agree - it shall be marked as: GR. The second premise is the qualifying judgement, which assigns, through a given ideological group, a specific attitude to a specific object - it shall be marked as: QJ. The conclusion, marked as $\mathbf{C}$, is a result of both premises, and must refer to both, the general rule and the qualifying judgement, and, just like a general or qualifying judgement in an axiological argumentation, it usually is not objective.

For Andrzej Mleczko's meme, one can recreate a simple axiological argumentation:

Argument 1:

GR: (Premise 1: general judgement / rule, which is known by all those who participate in a given culture or specific ideological group and/or with which they agree): The media should strive for objectivity in propagating information

QJ: (Premise 2: qualifying judgement, which assigns through a given ideological group a specific attitude to a specific object, missionaries in that case): Missionaries propagate Christian ideals ${ }^{11}$

C: (conclusion resulting from both premises): Missionaries are not objective Argument 2:

GR: The media should strive for objectivity in propagating information

QJ: Missionaries are not objective

C: Those media outlets where the shows are hosted by missionaries are not objective

The conclusion resulting from the second argument defines the meme's persuasive goal (within opinion discourse), i.e. to suggest to some and to confirm for others that currently the so-called public media are not objective and are subordinate to the ruling group.

${ }^{11}$ Missionary (in Latin missionarius) - a person sent by a church or a religious movement to propagate the Christian faith, as Jesus Christ said: "Go ye therefore, and teach all nations" (Matthew 28:19); https://pl.wikipedia.org/wiki/Misjonarz [accessed on: 08.04.2017]. 
That interpretation, remaining within the area of propaganda discourse, is overlaid with another interpretation of the meme, which forms part of the comical discourse. The transition to the latter constitutes the author's use of the polysemous nature of the words mission and missionary. Two meanings of the word mission are applied: 1. "an assignment, an important task to be fulfilled", and 3. "the activities of religious institutions carried out in order to propagate a religion and gain new followers; also: a centre conducting such activities" ${ }^{\prime 2}$. For the ruling party, both meanings are viewed as related, a fact which is mocked by the author of the meme. New arguments can be derived from those meanings. Argument 3 for the representatives of today's opposition and argument 4 for the representatives of today's ruling party. They include a common general rule and contrasted qualifying judgements, and in turn contrasted conclusions.

Argument 3:

GR: The media have an important task to fulfil = a mission

QJ: The mission of the media is objective information

C: Objective and free media fulfil their mission

That argument (3) is overlaid with the next argument (4), where public media are related to a religious institution:

Argument 4:

GR: Public media have an important task to fulfil $=$ a mission

QJ: An important task of public media is to propagate Christian values

C: The mission of public media is to propagate Christian values

For the representatives of the ideology of the ruling party, the word mission opens a script in which a missionary is associated with a journalist:

(t-2): BE CONVINCED (someone: MISSIONARY, about something: OF THE SUPERIORITY OF CHRISTIAN VALUES IN RELATION TO ALL OTHER VALUES)

(t-1): WANT TO [someone1: MISSIONARY, something1: CONVINCE (someone1: MISSIONARY, someone2: VIEWERS, to something2: TO THE SUPERIORITY OF CHRISTIAN VALUES IN RELATION TO OTHER VALUES)]

(t-0): CONTINUE TO CONVINCE [someone1: MISSIONARY, someone2: VIEWERS, to something: TO THE SUPERIORITY OF CHRISTIAN VALUES IN RELATION TO OTHER VALUES]

\footnotetext{
12 http://sjp.pwn.pl/slowniki/misja.html [accessed on: 08.04.2017].
} 
The humorous effect is evoked by the clash between the conclusion of argument 3 (Objective and free media fulfil their mission) and argument 4 (The mission of public media is to propagate Christian values), graphically expressed in the form of the surprised facial expression of the terrified viewer who was expecting the fulfilment of the mission of meaning 1 , and combining it with the natural reaction of the viewer's wife expressed as: Don't be so surprised, it's only natural for mission programmes to be hosted by missionaries, utilising meaning 3 of fulfilling the mission. Only through the correlation between the words and the image, can one understand the meme. The persuasive goal of comical discourse is to mock the deformed, according to the author of the meme, mission of the media.

The quoted example constitutes a rather mild method of mocking. Memes are dominated by a much more pungent manner of criticising politicians, one which utilises irony. They usually consist of a photograph of a politician and overlaid captions, where the photograph helps identify the person to whom the text applies.

Irony, similarly to metaphor, operates on two ideational images, whereas mockery does not require a reference to two images; it is enough to indicate the absurd nature of the message. The communicated ironic opinion is contrasted with the opinion proper, which the receiver must know or identify in the specific communicational situation. The aim of irony is to mock someone covertly (her/ his statements, actions, looks, etc.), an act which to be understood, to enable identification of the covert image, requires considerable effort on the part of the receiver, as well, of course, as discursive knowledge. Irony in a dual code communication may be introduced in various ways: the image may introduce a single piece of content while the caption another which remains in contrast with the significance of the image, thus together with the image forming an ironic message; irony may be created through the use of identically sounding words which exist in different semantic standards while the image leads the receiver to the proper meaning contrasted with the one included in the verbal text; irony is suggested by placing quotation marks over one word in the slogan, which offers for the receiver an instruction to shift to the contrast in relation to the meaning of the word; irony may be created as a result of referring to a statement of the person included in the photograph and leaving the act of referring it to the actual activities of said person; the reading of irony is mainly based on discursive knowledge - images do not influence the interpretation of a text, they only illustrate it, copy a part of the meaning, etc.

A classic example of mocking politicians is the focussing on their incompetence in various areas, as in the case of the memes mocking Urszula Dudziak, an expert of the Ministry of National Education (MEN), in terms of the preparation for a family life course. One such meme applied to Urszula Dudziak's attitude towards contraception: 


\section{Meme 2}

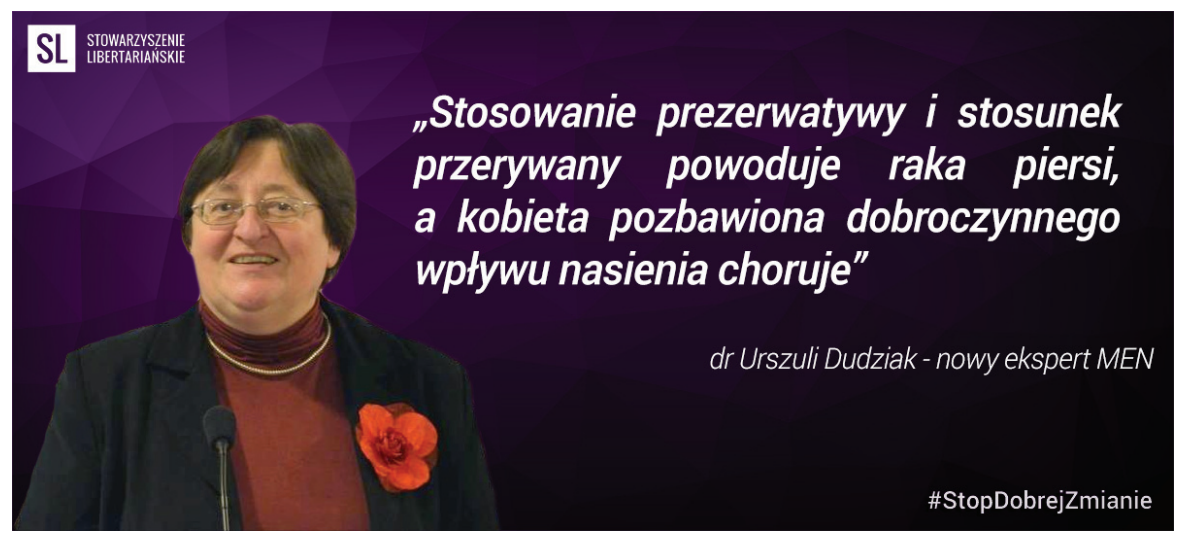

Source: https://i.redd.it/zc0mctnhndly.png [accessed on: 08.04.2017].

The general situational background for the meme was the discourse regarding family planning in Poland, particularly the debate regarding the availability of contraceptives and offering school children information regarding their use. In it, the views of the representatives of two polar options have clashed: liberals, who believe that having children should be a conscious decision of the future parents, makings it necessary to inform the young early on about the methods of preventing unwanted pregnancies; and conservatives, who believe that it is God that should decide who is to conceive a child while any form of contraception should be banned as it interferes with God's competences.

The specific situation which caused the creation of the meme was the development of an act banning the use of contraceptives and avoiding in school any information regarding them.

The humorous effect was achieved by the absurd nature of the quoted statement by Urszula Dudziak that: "The use of condoms and coitus interruptus causes breast cancer, while a woman deprived of the beneficial influence of semen becomes ill", which is contrary to medical knowledge and common sense. Thus two types of argumentation form.

Factual argumentation:

Premise 1 (general judgement which is agreed upon by all those who share a specific political view): The use of condoms, other contraceptives and coitus interruptus prevent undesired pregnancies

Premise 2 (qualifying judgement assigning specific behaviour to a specific object, in this case the youth): The young should learn about the functions of contraceptives, condoms and coitus interruptus 
Conclusion (resulting from both premises): Knowledge on contraceptives generally allows people to avoid undesired pregnancies.

Axiological argumentation (based on ideology and not medical knowledge):

Premise 1 (general judgement which is agreed upon by all those who share a specific political view): The use of condoms and coitus interreptus causes breast cancer and women becoming ill

Premise 2 (qualifying judgement assigning specific behaviour to a specific object, in this case the youth): The young should learn about the consequences of using condoms and coitus interruptus

Conclusion (resulting from both premises): The young should not use contraception.

The juxtaposition of the general judgements of the factual argument and the axiological argument offer a contrast which evokes a comical effect caused by the absurd association drawn between breast cancer and using condoms.

The ironic effect created through the overlaying of two ideational images: the first one implemented directly by Urszula Dudziak, which could be expressed according to the following pattern:

(image 1): CAUSE (something1: CONTRACEPTIVES, something2: BECOME ILL (someone: WOMAN, with something: BREAST CANCER]

and the second, which must be recreated based on commonly available knowledge, and can be expressed according to the following pattern:

(image 2): ENABLE [something1: CONTRACEPTIVES, something2: CONSCIOUS > PLAN (SOMEONE, something3: FAMILY)]

The fact that Urszula Dudziak substituted commonly accepted knowledge with her own idea indicates her incompetence in that respect, which in combination with her position as a MEN expert leads to introducing the argument:

Premise 1 (general judgement which is agreed upon by all those who participate in a specific culture): A MEN expert should be competent in terms of notions she/he is supposed to decide upon

Premise 2 (qualifying judgement assigning specific qualities to a specific object, in this case to Urszula Dudziak): Urszula Dudziak is incompetent

Conclusion (resulting from both premises): Urszula Dudziak should not be a MEN expert. 
That argumentation leads to another, propaganda argument:

Premise 1 (general judgement which is agreed upon by all those who participate in a specific culture): Currently, PiS rules in Poland

Premise 2 (qualifying judgement assigning specific qualities to a specific object, in this case to Urszula Dudziak): Urszula Dudziak was nominated by PiS \& Urszula Dudziak is incompetent

Conclusion (resulting from both premises): PiS nominates for official positions people who are incompetent $\rightarrow$ (which leads to): PiS does not include competent people, who could govern

And finally, the last example of an interpretation of a meme, which includes irony co-created by the graphic and verbal codes in such a way that the graphic code indicates one image, while the verbal code indicates another, thus creating the ironic effect:

\section{Meme 3}

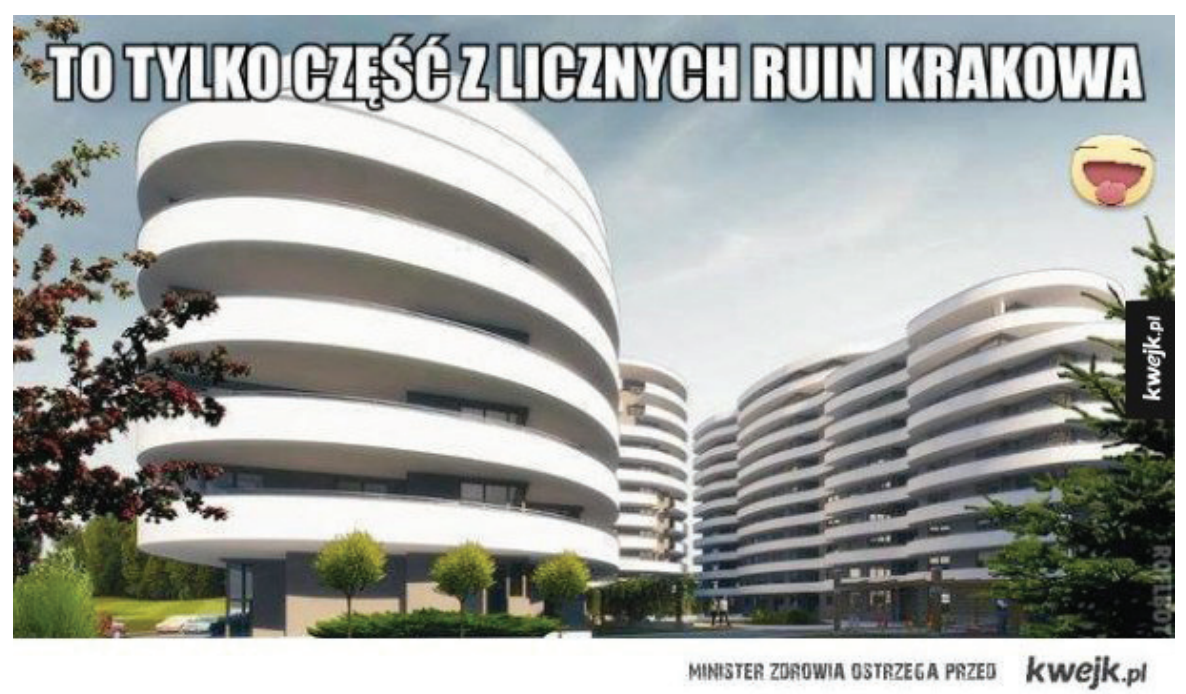

Source: http://bi.gazeta.pl/im/8b/44/11/z18104715Q,Polska-w-ruinie--mem.jpg [accessed on: 08.04.2017]. 
Meme 4

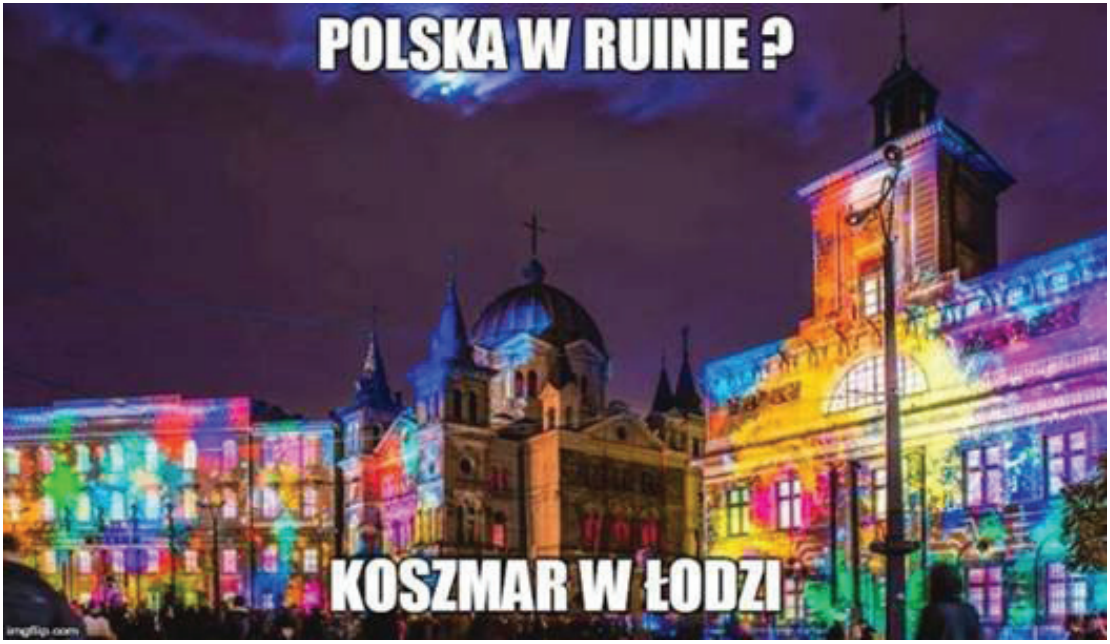

Source: http://www.poznajmemy.pl/wp-content/uploads/2015/09/ruina7.jpg [accessed on: 08.04.2017].

\section{Meme 5}

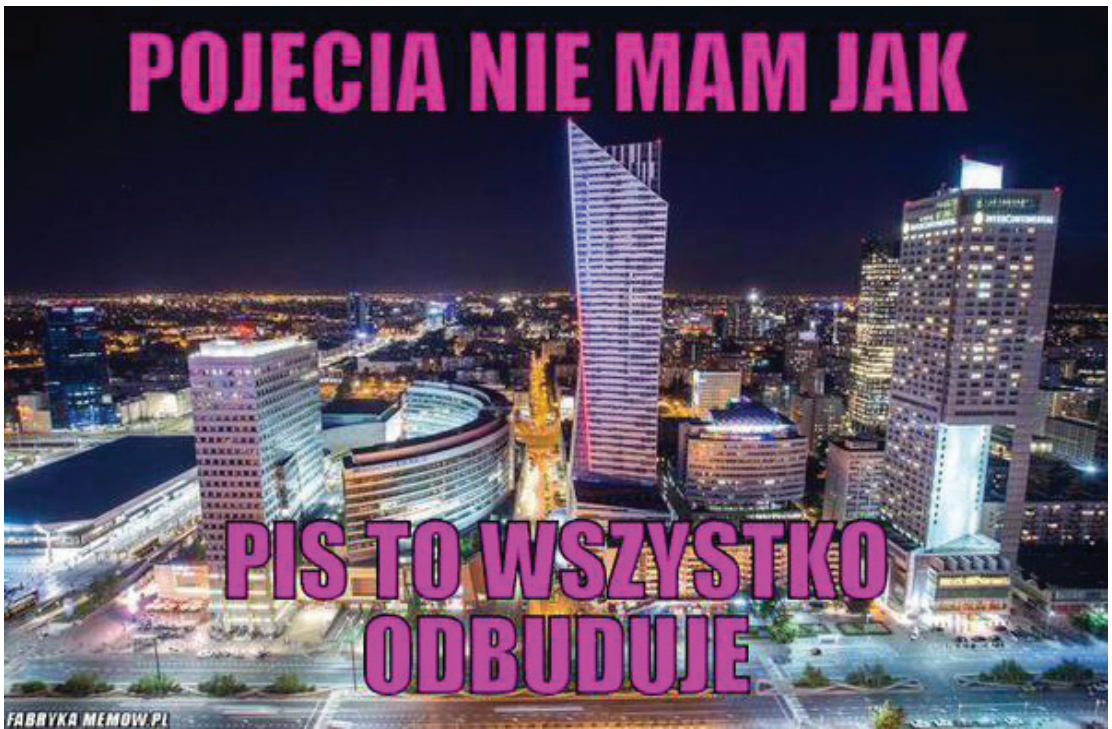

Source: http://gfx.archiwum.radiozet.pl/var/radiozetv3/storage/images/media/images/ mem-polska-w-ruinie/854464-1-pol-PL/Mem-Polska-w-ruinie_article-content-max.jpg [accessed on: 08.04.2017].

The general situational background of those memes was the pre-election discourse, where each political party tried to indicate the shortcomings and failings of their opponents. 
The specific situation which resulted in the creation of those memes was the slogan propagated by PiS that the previous ruling party had ruined Poland.

In response to the propagation of such opinions, opponents of PiS posted on the internet various memes, where the visual code showed blooming Polish cities, while the verbal code was the PiS slogan: Ruined Poland (Polska w ruinie), which remained in clear dissonance with the real situation. That juxtaposition introduced an ironic effect, where the reality presented in the photographs was dissonant with the text propagated by PiS, thus enabling the introduction of an argumentation:

Premise 1 (general judgement which is agreed upon by all those who participate in a specific culture): PiS claims that Poland has been ruined

Premise 2 (qualifying judgement, documenting reality): Photographs indicate that Poland is blooming

Conclusion (resulting from both premises): PiS is lying.

That conclusion offers grounds for creating another argument of a propaganda nature:

Premise 1 (general judgement which is agreed upon by all those who participate in a specific culture): A party that lies should not rule the country

Premise 2 (qualifying judgement, documenting reality): PiS lies

Conclusion (resulting from both premises): PiS should not rule the country.

As it soon turned out, in the election Poles did not follow any logical argument, though that remains outside the discussion herein.

To sum up, one can conclude that visual-verbal communications can be analysed just as verbal communications by applying the same criteria. In the case of opinion texts, and advertisements and memes are considered within that group, to understand them, the receiver must utilise her/his discursive knowledge, define the general background and the specific situation, recreate the factual and axiological argumentation, and identify the metaphors, irony and other devices which employ the receiver's emotions. Words and images offer different levels of communication interpretability. In the final three memes (3-5) and the analysed advertisement, there was a balance between the visual and verbal parts of the communication. In the first meme (1), the verbal message dominated the visual message, yet the image validated the interpretation of the verbal text. In the second meme (2), the interpretation was based on a verbal text while the photographs only indicated the object to which the verbal text applied. 


\section{Bibliography}

Awdiejew A., "Argumentacja aksjologiczna", in: "Rozmowy o komunikacji 2: Motywacja psychologiczna i kulturowa w komunikacji”, G. Habrajska (ed.), Oficyna Wydawnicza Leksem, Lask 2008, pp. 129-139.

Awdiejew A., "Podstawowe komponenty przekazu reklamowego", in: "Styl - dyskurs - media", B. Bogołębska, M. Worsowicz (eds.), Wydawnictwo Uniwersytetu Łódzkiego, Lodz 2010.

Awdiejew A., "Style argumentacji" (accepted for printing - Cracow 2016).

Awdiejew A., "Tryby komunikacyjne”, in: "W zwierciadle języka i kultury”, J. Adamowski, S. Niebrzegowska (eds.), Wydawnictwo Uniwersytetu Marii Curie-Skłodowskiej, Lublin 1999, pp. 240-247.

Awdiejew A., Habrajska G., "Strategie propagandowe i agitacyjne", in: "Rozmowy o komunikacji 3: Problemy komunikacji społecznej”, G. Habrajska (ed.), Oficyna Wydawnicza Leksem, Łask 2009, pp. 9-54.

Awdiejew A., Habrajska G., "Wprowadzenie do gramatyki komunikacyjnej”, Vol. 1, Oficyna Wydawnicza Leksem, Łask 2004.

Awdiejew A., Habrajska G., "Wprowadzenie do gramatyki komunikacyjnej”, Vol. 2, Oficyna Wydawnicza Leksem, Łask 2006.

http://sjp.pwn.pl/slowniki/misja.html [accessed on: 08.04.2017].

https://pl.wikipedia.org/wiki/Misjonarz [accessed on: 08.046.2017].

"Manual - reklama. Podręcznik z zakresu projektowania komunikacji”, M. Wszołek (ed.), Wydawnictwo Libron, Wroclaw 2017.

Paul-Cavallier F.J., "Wizualizacja. Od obrazu do działania”, transl. by A. Suchańska, Dom Wydawniczy Rebis, Poznan 1994.

\section{Grażyna Habrajska}

\section{Interpretation of a verbal-visual communication}

\section{(Summary)}

In contemporary internet-dominated everyday life, ever more often one faces communications which utilise both verbal (words) and iconic (images) codes. In the article, I analyse two types of said communications: advertisements and memes. Both advertising content and memes belong to journalistic discourse. Therefore, one can analyse them using the same methods as verbal opinion texts, which require one to specify the situational background, the specific situation, the persuasive/ propaganda aim, and to standardise arguments. At the same time, memes are included in comical discourse, to analyse which it is necessary to be able to juxtapose the actual image with the presented image.

Keywords: dual code communication, text analysis, journalistic discourse, comical discourse, advertising, meme, visual communication. 